\title{
PENERAPAN MODEL PEMBELAJARAN MAKE A MATCH DENGAN MEDIA KARTU BERGAMBAR UNTUK MENINGKATKAN MOTIVASI DAN HASIL BELAJAR SISWA
}

\author{
Iis Daniati Fatimah \\ Universitas Negeri Malang, Jalan Semarang 5 Malang 65145 \\ E-mail: iisdaniatifatimah@gmail.com
}

\begin{abstract}
Implementation of "Make A Match" Learning Model with Picture Cards to Improve Motivation and Learning Outcomes for Student. This study aimed to describe the application of learning models make a match with the picture card media as well as to determine the increase in motivation and learning outcomes third grade students of Public Elementary School Kranjingan 5 Jember (SDN Kranjingan 5 Jember) after application of learning models make a match with the picture card media. This study uses classroom action research. This study using two cycles, each cycle consisting of three meetings. The subjects were students of class III SDN Kranjingan 5 Jember with 30 students.
\end{abstract}

Keywords: make a match model, picture cards, motivation, learning outcomes

\begin{abstract}
Abstrak: Penerapan Model Pembelajaran Make A Match dengan Media Kartu Bergambar untuk Meningkatkan Motivasi dan Hasil Belajar Siswa. Penelitian ini bertujuan untuk mendeskripsikan penerapan model pembelajaran make a match dengan media kartu bergambar serta untuk mengetahui peningkatan motivasi dan hasil belajar siswa kelas III SDN Kranjingan 5 Jember setelah penerapan model pembelajaran make a match dengan media kartu bergambar. Penelitian ini menggunakan penelitian tindakan kelas. Penelitian ini dengan menggunakan dua siklus, setiap siklus terdiri dari 3 pertemuan. Subjek penelitian adalah siswa kelas III SDN Kranjingan 5 Jember yang berjumlah 30 siswa.
\end{abstract}

Kata kunci: model make a match, media kartu bergambar, motivasi, hasil belajar

Ilmu pengetahuan Sosial (IPS) merupakan salah satu mata pelajaran yang berguna untuk meningkatkan ketrampilan, sikap dan nilai. Pengalaman belajar dilakukan serangkaian kegiatan untuk membelajarkan siswa melalui interaksi aktif dengan teman, lingkungan dan narasumber lainnya. Belajar IPS bagi siswa pada saat ini adalah usaha untuk menumbuhkan dan mengembangkan sikap, ketrampilan berpikir, serta meningkatkan ketrampilan motoriknya bukan sekedar usaha untuk mencari dan mengumpulkan pengetahuan tentang peristiwa masa lampau, nama-nama suatu daerah, dan sosial ekonomi.

Kenyataan yang ada di SDN Kranjingan 5 Jember, ketika pembelajaran IPS dilaksanakan oleh guru, masih cenderung konvensional dengan metode ceramah, tanya-jawab klasikal, kadangkadang saja guru melakukan diskusi kelompok.
Buku teks masih menjadi acuan utama guru sebagai sumber belajar. Pembelajaran IPS masih sangat dominan dengan hafalan. Akibatnya, ketrampilan sosial yang diharapkan dimiliki siswa setelah proses pembelajaran belum tercapai. Sikap saling menghormati, sikap kritis, sikap untuk selalu berprestasi, saling menghargai, dan sikapsikap lain yang merupakan bagian dari tujuan pembelajaran IPS masih jauh dari harapan.

Dalam kurikulum mata pelajaran IPS Sekolah Dasar dijelaskan bahwa tujuan mata pelajaran IPS supaya peserta didik memiliki kemampuan sebagai berikut: (1) mengenal konsep-konsep yang berkaitan dengan kehidupan masyarakat dan lingkungannya; (2) memiliki kemampuan dasar untuk berpikir logis dan kritis, rasa ingin tahu, inkuiri, memecahkan masalah, dan ketrampilan dalam kehidupan sosial; (3) memiliki komitmen 
dan kesadaran terhadap nilai-nilai sosial dan kemanusiaan; dan (4) memiliki kemampuan berkomunikasi, bekerjasama dan berkompetisi dalam masyarakat yang majemuk, di tingkat lokal, nasional, dan global.

Tujuan pembelajaran tersebut, ternyata masih belum terlihat pada pembelajaran IPS di SDN Kranjingan 5 Jember. Hal ini disebabkan karena pembelajaran yang telah dirancang oleh guru kurang dapat mengaktifkan siswa baik dalam pengetahuan tentang konsep maupun ketrampilan sosial siswa. Dengan kondisi ini, maka memungkinkan siswa bosan untuk belajar IPS. Ketika kebosanan mendominasi siswa, maka motivasi siswa dalam belajar IPS akan rendah. Temuan awal peneliti, rendahnya motivasi belajar IPS siswa ditunjukkan dengan berbagai aktivitas. Misal, ketika guru memberikan materi pelajaran banyak siswa yang ramai sendiri, bercanda dengan teman sebangkunya, ijin keluar masuk kelas dengan alasan ke kamar mandi, siswa kurang merespon stimulus dari guru, kepasifan siswa menyebabkan guru sulit mengetahui apakah siswa sudah paham atau belum terhadap materi yang telah disampaikan.

Siswa yang terlibat dalam proses pembelajaran sering merasakan pembelajaran sebagai beban daripada upaya untuk aktif memperdalam ilmu. Akibatnya motivasi belajar siswa rendah, siswa merasa terbebani dan bosan terhadap apa yang dihadapinya. Winkel (1996) menyatakan motivasi belajar adalah keseluruhan daya penggerak psikis di dalam diri siswa yang menimbulkan kegiatan belajar, menjamin kelangsungan kegiatan belajar dan memberikan arahan pada kegiatan belajar demi mencapai suatu tujuan pembelajaran. Ketika siswa sudah tidak termotivasi untuk belajar dan tidak lagi memusatkan pikiran untuk belajar hal ini dapat menyebabkan motivasi rendah dan hasil belajar siswa yang belum mencapai KKM mata pelajaran IPS di SDN Kranjingan 5.

Berdasarkan hasil wawancara dan observasi peneliti dengan Ibu $\mathrm{Wr}$ selaku guru mata pelajaran IPS kelas III, diketahui bahwa hasil ulangan siswa dengan kompetensi dasar mengenal jenisjenis pekerjaan, hasilnya rendah. Adapun nilai para siswa yaitu 22 siswa mendapat nilai $\leq 75$ (73\% siswa yang belum tuntas) dan 8 siswa mendapatkan nilai $\geq 75$ (27\% siswa yang tuntas).
Paparan nilai tersebut belum memenuhi kriteria ketuntasan minimal (KKM) SDN Kranjingan 5 baik ketuntasan individu maupun klasikal siswa (75\% siswa yang tuntas belajar IPS dengan nilai $\geq 75$ ).

Berdasarkan permasalahan tersebutdiperlukan pembelajaran yang dapat meningkatkan motivasi dan hasil belajar siswa. Motivasi merupakan komponen pembelajaran yang terpenting (Slavin, 2006), maka pembelajaran akan berhasil jika siswa memiliki motivasi dalam belajar. Oleh sebab itu, menumbuhkan motivasi belajar siswa merupakan tugas dan tanggung jawab guru. Guru yang baik dalam mengajar senantiasa berusaha mendorong siswa untuk beraktivitas mencapai tujuan pembelajaran. Siswa memiliki bermacam-macam motivasi dalam belajar (Dimyati \& Mudjiono, 2006). Siswa yang memiliki motivasi belajar tinggi cenderung prestasinya pun tinggi, sebaliknya siswa yang motivasi belajarnya rendah, akan rendah pula prestasinya (Sanjaya, 2009).

Upaya untuk mengatasi permasalahan tersebut, salah satunya dengan cara memilih model pembelajaran yang tepat. Pembelajaran tersebut adalah cooperative learning. Mengajar dengan menggunakan pembelajaran kooperatif dapat meningkatkan ketrampilan sosial. Guru dituntut untuk mampu mengembangkannya karena tidak semua siswa tahu bagaimana berinteraksi dengan siswa lain (Arends, 2004). Teori- teori Vigotsky mendukung penggunaan pembelajaran dengan kerjasama (cooperative) di mana anakanak dapat bekerja sama untuk saling membantu belajar sehingga mereka dapat memperoleh pemahaman tentang proses penalaran satu sama lain (Slavin, 2008). Peneliti memilih pembelajaran kooperatif model make a match karena didukung dengan penelitian sebelumnya yang menyebutkan bahwa model make a match dengan media kartu bergambar dapat meningkatkan motivasi dan hasil belajar siswa.

Lie (2002) menyebutkan make a match mengemas pembelajaran mengenai suatu konsep dalam suasana belajar yang menyenangkan. Melalui media bergambar siswa akan tertarik untuk mengikuti pembelajaran, seperti dikemukakan oleh (Arsyad, 2009) istilah media sebagai perantara yang mengantar informasi antara sumber dan penerima. Jadi, televisi, film, foto, radio, rekaman audio, 
gambar yang diproyeksikan bahan bahan cetakan dan sejenisnya adalah media komunikasi. Apabila media itu membawa pesan-pesan atau informasi yang bertujuan instruksional atau mengandung maksud pembelajaran maka media itu disebut media pembelajaran. Jika pembelajaran dirancang dengan make a match menyenangkan, dan adanya media kartu bergambar dapat menyampaikan pesan instruksional maka hal ini memperkuat ketrampilan sosial siswa, menciptakan suasana belajar gembira, membuat siswa termotivasi dalam belajar dan hasil belajar yang diinginkan dapat terwujud.

\section{METODE}

Jenis penelitian ini adalah penelitian tindakan kelas (PTK). Dalam PTK terjadi kerjasama antara peneliti dengan guru dan dua orang observer yang membantu dalam pengamatan untuk mengambil data selama penelitian (Wiraatmadja, 2007). Desain penelitian yang digunakan mengacu pada model Kemmis dan McTaggart yang terdiri empat komponen, yaitu: perencanaan tindakan, pelaksanaan tindakan, observasi, dan refleksi (Susilo, dkk., 2008). Penelitian ini dilakukan dengan 2 siklus. Tiap siklus dilaksanakan perbaikanperbaikan yang ingin dicapai melalui tahap refleksi. Selanjutnya memperoleh informasi tentang kondisi pembelajaran dan kondisi awal di kelas sebelum dilakukan tindakan. Adapun prosedur penelitian tindakan kelas dapat diilustrasikan pada Gambar 1.

Subjek penelitian adalah siswa kelas III SDN Kranjingan 5 Jember tahun ajaran 2011/2012 yang berjumlah 30 siswa. Para siswa tersebut terdiri dari 15 putra dan 15 putri. Dari segi akademik, para siswa mempunyai kemampuan akademik yang heterogen. Prosedur pengumpulan data yang digunakan dalam penelitian ini terdiri atas: (1) observasi, dilakukan dengan cara observasi sistematis dengan pedoman yang telah disiapkan. Data yang diperoleh dalam penelitian ini yaitu aktivitas guru dalam penerapan pembelajaran kooperatif model make a match dan motivasi siswa selama kegiatan belajar mengajar. Observasi pada penelitian ini dilakukan oleh peneliti dan

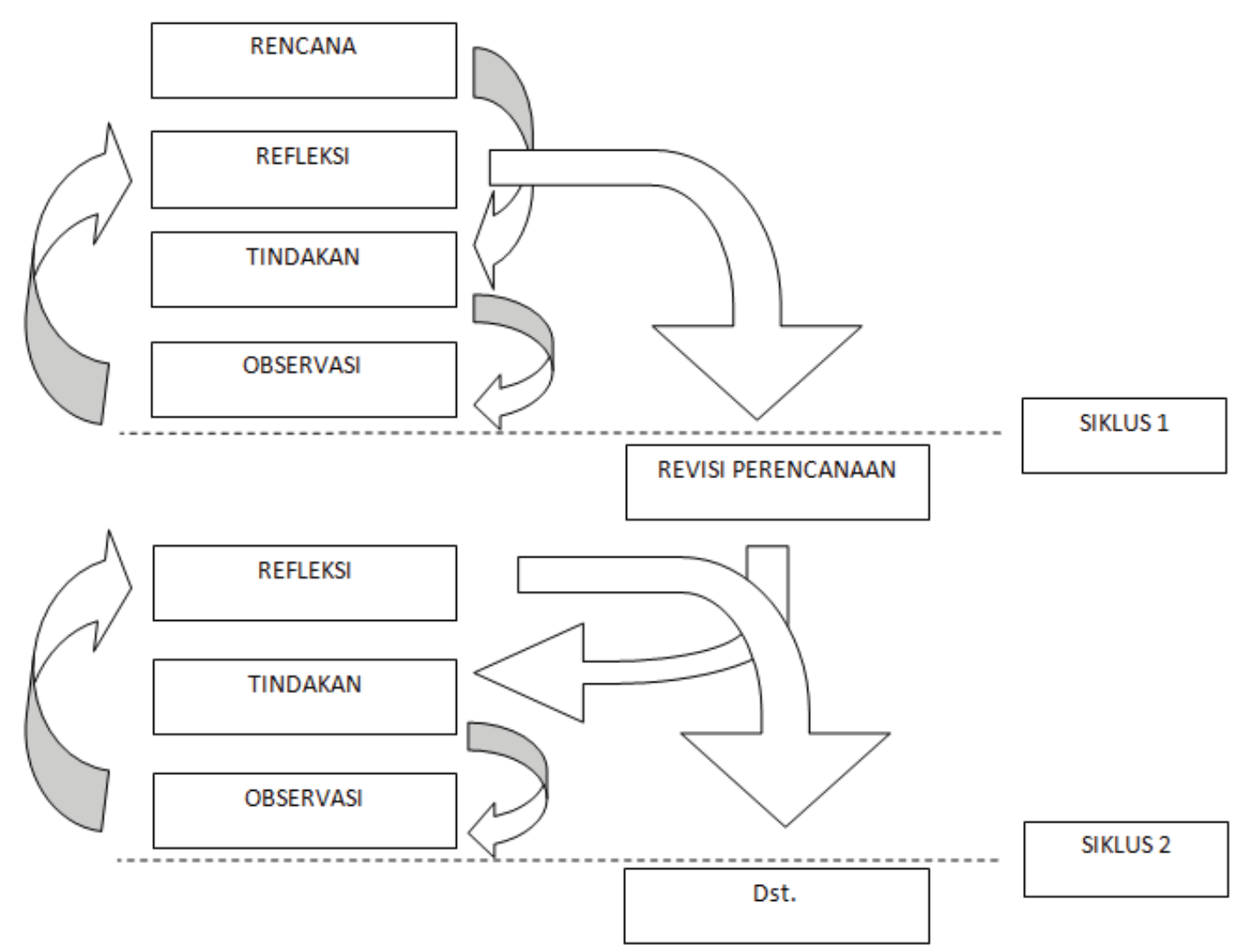

Gambar 1 Desain PTK Model Kemmis \& Mc Taggart

(Sumber: Susilo, dkk., 2008) 
dibantu oleh observer yaitu Putra Johan Bahagia; (2) tes, digunakan untuk mengumpulkan data hasil belajar siswa. Tes yang digunakan adalah tes buatan guru yang bentuk dan isinya telah dikonsultasikan dengan guru mata pelajaran IPS dan dosen pembimbing. Bentuk tes berupa tes objektif (pilihan ganda). Tes dilaksanakan sesudah pembelajaran (post-test), tujuannya adalah untuk mengkaji ketuntasan hasil belajar yang dicapai siswa setelah proses pembelajaran; dan (3) angket motivasi, diberikan untuk mengukur motivasi belajar IPS siswa. Angket ini diberikan dua kali yaitu setelah selesai pemberian tindakan pada Siklus I dan Siklus II.

Keller telah menyusun seperangkat prinsipprinsip motivasi yang dapat diterapkan dalam kegiatan pembelajaran yang disebut sebagai model ARCS, yakni attention, relevance, confidence, satisfaction (Setiawan, 2005). Angket yang diberikan mengandung unsur-unsur dalam motivasi belajar yang meliputi perhatian terhadap pelajaran (attention), keterkaitan (relevance), keyakinan diri/percaya diri (confidence), dan kepuasan (satisfaction). Dokumentasi dalam penelitian ini digunakan sebagai bukti fisik kegiatan penelitian. Dokumentasi dalam penelitian ini berupa RPP, LKS dan foto-foto yang menggambarkan aktivitas guru dan siswa selama proses pembelajaran di kelas.

Lembar observasi aktivitas siswa ini dibuat untuk memperoleh gambaran tentang aktivitas siswa selama proses pembelajaran berlangsung. Aktivitas siswa dalam mengikuti proses pembelajaran diskor berdasarkan aktivitas-aktivitas siswa di dalam kelas. Aktivitas-aktivitas siswa pada proses pembelajaran yang diamati adalah aktivitas siswa pada saat bertanya, mengeluarkan pendapat, bekerja dalam kelompok dan diskusi. Data hasil observasi aktivitas siswa dianalisis dengan menggunakan rumus:

Persentase $(\mathrm{NR})=\frac{\text { jumlah skor }}{\text { skor maksimal }} \times 100 \%$

Taraf keberhasilannya:

$90 \% \leq \mathrm{NR} \leq 100 \%$ : sangat baik

$80 \% \leq \mathrm{NR}<90 \%$ : baik

$70 \% \leq \mathrm{NR}<80 \%$ : cukup

$60 \% \leq \mathrm{NR}<70 \%$ : kurang

$0 \% \leq \mathrm{NR}<60 \% \quad$ : sangat kurang
Aktivitas siswa dikatakan baik jika rata-rata skor dari semua aspek yang dinilai berada pada kategori baik atau sangat baik. Dengan demikian, maka hasil analisis data yang tidak memenuhi dari salah satu kategori baik atau sangat baik pada penelitian ini akan dijadikan bahan pertimbangan untuk merevisi perangkat pembelajaran yang telah diujicobakan. Lembar observasi aktivitas guru ini dibuat untuk memperoleh gambaran tentang kemampuan guru dalam mengelola pembelajaran. Kegiatan guru yang diobservasi disini adalah kemampuan guru dan aktivitas guru dalam mengelola proses pembelajaran. Pedoman penskoran berdasarkan banyaknya deskriptor yang dilakukan oleh guru. Data hasil pengamatan aktivitas guru dalam mengelola pembelajaran dianalisis dengan menggunakan rumus:

$$
\text { Persentase }(N R)=\frac{\text { jumlah skor }}{\text { skor maksimal }} \times 100 \%
$$

Taraf keberhasilannya:

$90 \% \leq \mathrm{NR} \leq 100 \%$ : sangat baik

$80 \% \leq \mathrm{NR}<90 \%$ : baik

$70 \% \leq \mathrm{NR}<80 \%$ : cukup

$60 \% \leq \mathrm{NR}<70 \%$ : kurang

$0 \% \leq \mathrm{NR}<60 \% \quad$ : sangat kurang

Kemampuan guru dalam mengelola pembelajaran dikatakan baik jika rata-rata skor dari semua aspek yang dinilai berada pada kategori baik atau sangat baik. Data peningkatan motivasi siswa diambil dengan memberikan angket dan lembar observasi pada setiap akhir siklus. Persentase keberhasilan motivasi dihitung dengan menggunakan rumus:

$$
\text { Keberhasilan Motivasi }=\frac{\text { jumlah skor }}{\text { skor maksimal }} \times 100 \%
$$

Penentuan tingkat keberhasilan:

$$
\begin{array}{ll}
80-100 & =\text { sangat baik } \\
60-79 & =\text { baik } \\
40-59 & =\text { cukup } \\
10-39 & =\text { kurang } \\
0-9 & =\text { sangat kurang }
\end{array}
$$

Peneliti mengharapkan motivasi belajar siswa dapat meningkat dengan pembelajaran model make a match dengan target $\geq 75 \%$ siswa yang mendapat skor motivasi $\geq 75$. Data angket tersebut dihitung dan dianalisis berdasarkan skor untuk masing- masing aspek. Data hasil belajar 
siswa diambil dengan memberikan tes pada setiap akhir siklus. Data hasil belajar dianalisis dengan menggunakan ketuntasan individual dan ketuntasan klasikal terhadap indikator yang telah ditetapkan. Ketuntasan individual atau ketuntasan per siswa ditentukan dengan rumus:

$$
\begin{aligned}
& \mathrm{K}=\frac{\mathrm{T}}{\mathrm{Tt}} \times 100 \% \\
& \mathrm{~K}: \begin{array}{r}
\text { Persentase ketuntasan belajar siswa per } \\
\text { siswa (proporsi jawaban yang benar) }
\end{array} \\
& \mathrm{T}: \text { Jumlah indikator yang tuntas per siswa } \\
& \mathrm{Tt}: \text { Jumlah indikator keseluruhan }
\end{aligned}
$$

Sebagai standar ketuntasan belajar digunakan patokan yang ditetapkan oleh SDN Kranjingan 5 Jember pada KKM (Kriteria Ketuntasan Minimal) mata pelajaran IPS 75, yaitu siswa dikatakan tuntas belajarnya jika memenuhi nilai $\mathrm{KKM} \geq 75$ dan untuk ketuntasan klasikal $75 \%$ siswa yang mendapat nilai $\geq 75$.

\section{HASIL}

\section{Peningkatan Motivasi Belajar Siswa Menggunakan Model Make A Match}

Penelitian ini bertujuan untuk mengetahui peningkatan yang terjadi dari siklus I ke siklus II dengan menggunakan lembar observasi motivasi dan angket yang diberikan kepada siswa. Angket motivasi terdiri dari 30 pernyataan dimana pada

\begin{tabular}{|c|c|c|c|c|c|c|c|c|c|c|}
\hline \multirow{2}{*}{ Pernyataan } & \multicolumn{10}{|c|}{ Keterangan } \\
\hline & SS & $\%$ & $\mathrm{~s}$ & $\%$ & $\mathrm{RR}$ & $\%$ & TS & $\%$ & STS & $\%$ \\
\hline 1 & 10 & 33 & 8 & 27 & 12 & 40 & & 0 & & 0 \\
\hline & & 13 & & & 13 & & 2 & 7 & 2 & \\
\hline 3 & $\because$ & 0 & $\frac{3}{2}$ & 7 & 13 & 43 & 13 & 43 & 2 & 7 \\
\hline 4 & 1 & 3 & 9 & 30 & 11 & 37 & 6 & 20 & 3 & 10 \\
\hline 5 & 2 & 7 & 10 & 33 & 12 & 40 & 4 & 13 & 2 & 7 \\
\hline 6 & 5 & 16 & 5 & 16 & 11 & 37 & 6 & 20 & 3 & 10 \\
\hline 7 & 5 & 16 & 10 & 33 & 13 & 43 & 1 & 3 & 1 & 3 \\
\hline 8 & 6 & 20 & 14 & 47 & 10 & 33 & - & 0 & - & 0 \\
\hline 9 & 6 & 20 & 16 & 54 & 8 & 27 & - & 0 & - & 0 \\
\hline 10 & 9 & 30 & 8 & 27 & 12 & 40 & 1 & 3 & - & 0 \\
\hline 11 & 1 & 3 & 13 & 43 & 10 & 33 & 6 & 20 & 1 & 3 \\
\hline 12 & 1 & 3 & 13 & 43 & 12 & 40 & 4 & 13 & - & 0 \\
\hline 13 & 4 & 13 & 8 & 27 & 10 & 33 & 8 & 27 & $=$ & 0 \\
\hline 14 & 2 & 7 & 9 & 30 & 5 & 16 & 10 & 33 & 4 & 13 \\
\hline 15 & 1 & 3 & 7 & 23 & 16 & 54 & 4 & 13 & 2 & 7 \\
\hline 16 & 3 & 10 & 8 & 27 & 7 & 23 & 8 & 27 & 4 & 13 \\
\hline 17 & 2 & 7 & 9 & 30 & 9 & 30 & 7 & 23 & 3 & 10 \\
\hline 18 & 4 & 13 & 8 & 27 & 14 & 47 & 3 & 10 & 1 & 3 \\
\hline 19 & 7 & 23 & 11 & 37 & 7 & 23 & 3 & 10 & 2 & 7 \\
\hline 20 & 10 & 33 & 6 & 20 & 7 & 23 & 7 & 23 & & 0 \\
\hline 21 & 4 & 13 & 11 & 37 & 11 & 37 & 2 & 7 & 2 & 7 \\
\hline & 5 & 16 & 11 & 37 & 8 & 27 & 4 & 13 & & 7 \\
\hline 23 & 5 & $\begin{array}{l}16 \\
16\end{array}$ & 10 & 33 & 5 & 16 & 8 & $\begin{array}{l}13 \\
27\end{array}$ & 2 & 7 \\
\hline 24 & 5 & 16 & 7 & 23 & 11 & 37 & 5 & 16 & 2 & 7 \\
\hline 25 & 2 & 7 & 10 & 33 & 12 & 40 & 4 & 13 & 2 & 7 \\
\hline 26 & 4 & 13 & 10 & 33 & 7 & 23 & 9 & 30 & 2 & 7 \\
\hline 27 & 2 & 7 & 9 & 30 & 10 & 33 & 7 & 23 & 2 & 7 \\
\hline 28 & 3 & 10 & 10 & 33 & 10 & 33 & 5 & 16 & 2 & 7 \\
\hline 29 & 6 & 20 & 12 & 40 & 6 & 20 & 5 & 16 & 1 & 4 \\
\hline 30 & 7 & 22 & 18 & 60 & 4 & 12 & - & 0 & 1 & 7 \\
\hline
\end{tabular}
saat mengisi angket guru menemani mereka di dalam kelas. Adapun keterangan peningkatan motivasi ditampilkan pada Tabel 1.

\section{Tabel 1 Motivasi Siswa Siklus I}

Berdasarkan Tabel 1 tersebut menunjukkan masih banyak siswa yang mengisi pernyataan dalam angket dengan memberi tanda check-list ragu-ragu terhadap keberlangsungan pembelajaran IPS menggunakan model make a match. Maka, dengan hasil seperti ini diperlukan siklus berikutnya

\begin{tabular}{|c|c|c|c|c|c|c|c|c|c|c|}
\hline \multirow{2}{*}{ Pernyataan } & \multicolumn{10}{|c|}{ Keterangan } \\
\hline & SS & $\%$ & $\mathbf{S}$ & $\%$ & RR & $\%$ & TS & $\%$ & STS & $\%$ \\
\hline 1 & 17 & 57 & 8 & 27 & 5 & 16 & - & 0 & - & 0 \\
\hline 2 & 9 & 30 & 14 & 47 & 4 & 13 & 1 & 3 & 2 & 7 \\
\hline 3 & - & 0 & 18 & 60 & 8 & 27 & 4 & 13 & - & 0 \\
\hline 4 & 1 & 3 & 17 & 57 & 8 & 27 & 4 & 13 & - & 0 \\
\hline 5 & 2 & 7 & 18 & 60 & 8 & 27 & 2 & 7 & - & 0 \\
\hline 6 & 6 & 20 & 13 & 43 & 8 & 27 & 3 & 10 & - & 0 \\
\hline 7 & 6 & 20 & 14 & 47 & 6 & 20 & 4 & 13 & - & 0 \\
\hline 8 & 4 & 13 & 21 & 70 & 5 & 16 & - & 0 & - & 0 \\
\hline 9 & 5 & 16 & 16 & 54 & 9 & 30 & - & 0 & - & 0 \\
\hline 10 & 7 & 23 & 15 & 50 & 7 & 23 & 1 & 3 & - & 0 \\
\hline 11 & 2 & 7 & 18 & 60 & 8 & 27 & 2 & 7 & - & 0 \\
\hline 12 & 1 & 3 & 18 & 60 & 8 & 27 & 3 & 10 & - & 0 \\
\hline 13 & 5 & 16 & 13 & 43 & 9 & 30 & 3 & 10 & - & 0 \\
\hline 14 & 2 & 7 & 16 & 54 & 5 & 16 & 7 & 23 & - & 0 \\
\hline 15 & 2 & 7 & 19 & 63 & 7 & 23 & 2 & 7 & - & 0 \\
\hline 16 & 2 & 7 & 19 & 63 & 9 & 30 & - & 0 & - & 0 \\
\hline 17 & 3 & 10 & 13 & 43 & 8 & 27 & 4 & 13 & 2 & 7 \\
\hline 18 & 6 & 20 & 12 & 40 & 10 & 33 & - & 0 & 2 & 7 \\
\hline 19 & 7 & 23 & 13 & 43 & 6 & 20 & 3 & 10 & 1 & 3 \\
\hline 20 & 8 & 27 & 7 & 23 & 9 & 30 & 6 & 20 & - & 0 \\
\hline 21 & 3 & 10 & 14 & 47 & 9 & 30 & 2 & 7 & 2 & 7 \\
\hline 22 & 7 & 23 & 12 & 40 & 7 & 23 & 2 & 7 & 2 & 7 \\
\hline 23 & 5 & 16 & 11 & 37 & 6 & 20 & 6 & 20 & 2 & 7 \\
\hline 24 & 5 & 16 & 13 & 43 & 9 & 30 & 2 & 7 & 1 & 3 \\
\hline 25 & 3 & 10 & 12 & 40 & 11 & 37 & 3 & 10 & 1 & 3 \\
\hline 26 & 3 & 10 & 16 & 54 & 5 & 17 & 6 & 20 & - & 0 \\
\hline 27 & 4 & 13 & 17 & 57 & 6 & 20 & 3 & 10 & - & 0 \\
\hline 28 & 3 & 10 & 15 & 50 & 6 & 20 & 4 & 13 & 2 & 7 \\
\hline 29 & 7 & 23 & 13 & 43 & 6 & 20 & 3 & 10 & 1 & 3 \\
\hline 30 & 5 & 16 & 21 & 70 & 4 & 14 &. & 0 & - & 0 \\
\hline
\end{tabular}
untuk memotivasi siswa lebih baik lagi. Berikut ini adalah hasil angket Siklus II yang tertulis dalam Tabel 2.

\section{Tabel 2 Motivasi Siswa Siklus II}

Nilai yang terdapat di dalam Tabel 2 tersebut menunjukkan motivasi siswa kelas 3 SDN Kranjingan 5 Jember yang mengalami peningkatan, terutama dari siklus I yang semula banyak siswa yang mengisi pernyataan dengan menjawab ragu- ragu maka di siklus ke II ini sudah sedikit keraguan dan terlihat dari persentase yang banyak adalah memilih sangat senang atau senang dengan diadakannya pembelajaran IPS materi jenis-jenis pekerjaan dengan menggunakan model make a macth.

\section{Peningkatan Hasil Belajar Siswa Menggunakan Model Make A Match}

Adapun peningkatan ketuntasan hasil belajar mulai dari pra siklus, siklus I dan siklus II disajikan dalam Gambar 2. 


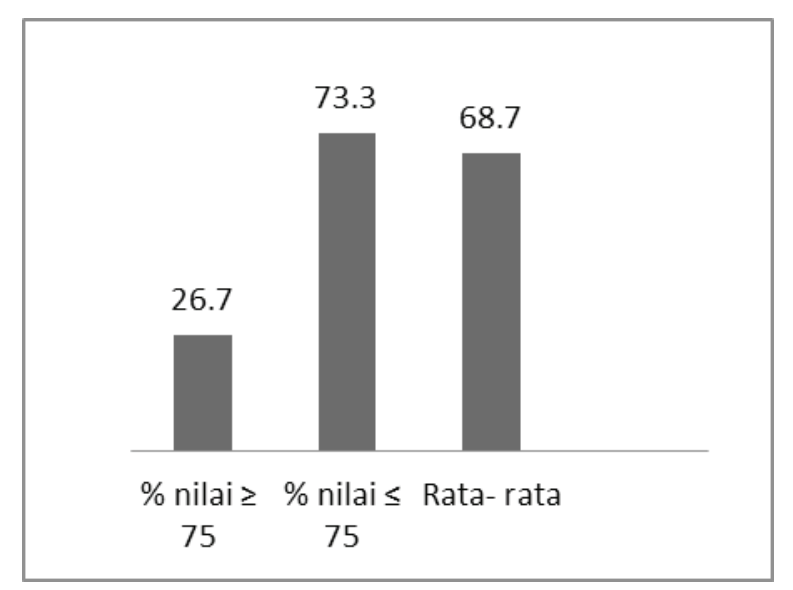

\section{Gambar 2 Nilai Hasil Belajar Prasiklus}

Siswa yang memperoleh nilai $\geq 75$ sebanyak $26 \%$ (8 siswa), sedangkan yang memperoleh nilai $\leq 75$ adalah $74 \%$ (22 siswa) dengan nilai rata-rata kelas sebanyak 68,7 . Oleh karena itu, diperlukan tindakan untuk memperbaiki nilai hasil belajar dari siklus I. Adapun hasil belajar siklus I disajikan dalam Gambar 3.

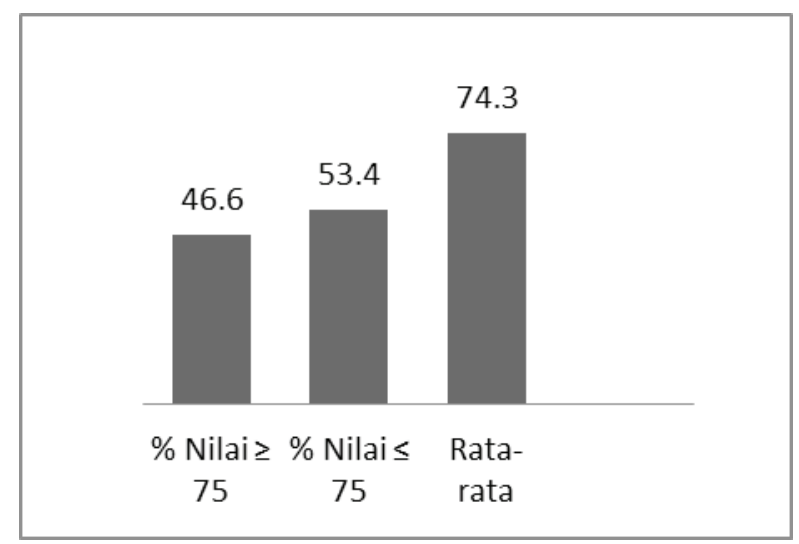

\section{Gambar 3 Nilai Hasil Belajar Siklus I}

Berdasarkan gambar tersebut diketahui bahwa siswa yang memperoleh nilai $\geq 75$ yaitu $46.6 \%$ (14 siswa), yang memperoleh nilai $\leq 75$ adalah 53.4\% (16 siswa) dengan nilai rata-rata kelas yaitu 74.3. Maka diperlukan tindakan untuk memperbaiki nilai hasil belajar supaya mencapai KKM mata pelajaran IPS. Oleh karena itu, siklus II perlu dilaksanakan. Adapun gambar hasil belajar siklus II disajikan dalam Gambar 4.

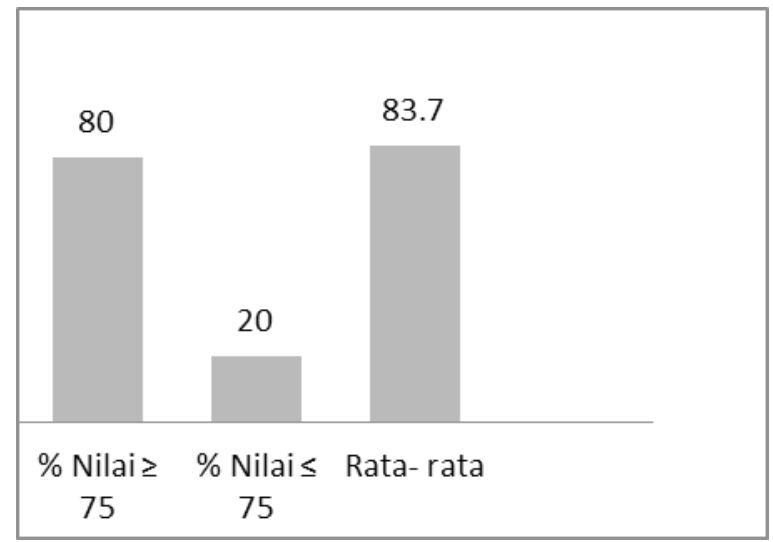

\section{Gambar 4 Nilai Hasil Belajar Siklus II}

Siswa yang memperoleh nilai $\geq 75$ yaitu $80 \%$ (24 siswa), yang memperoleh nilai $\leq 75$ adalah $6 \%$ (16 siswa) dengan nilai rata-rata kelas yaitu 83.7. Maka, dapat disimpulkan bahwa pada Siklus II nilai hasil belajar siswa mencapai KKM mata pelajaran IPS. Oleh karena itu, tidak perlu dilakukan tindakan selanjutnya. Selanjutnya berikut ini disajikan gambar peningkatan ketuntasan hasil belajar siswa kelas 3 SDN Kranjingan 5 Jember mata pelajaran IPS materi jenis-jenis pekerjaan mulai dari tahap prasiklus (Siklus I dan Siklus II). Peningkatan ketuntasan hasil belajar prasiklus (Siklus I dan Siklus II) ditampilkan pada Gambar 5.

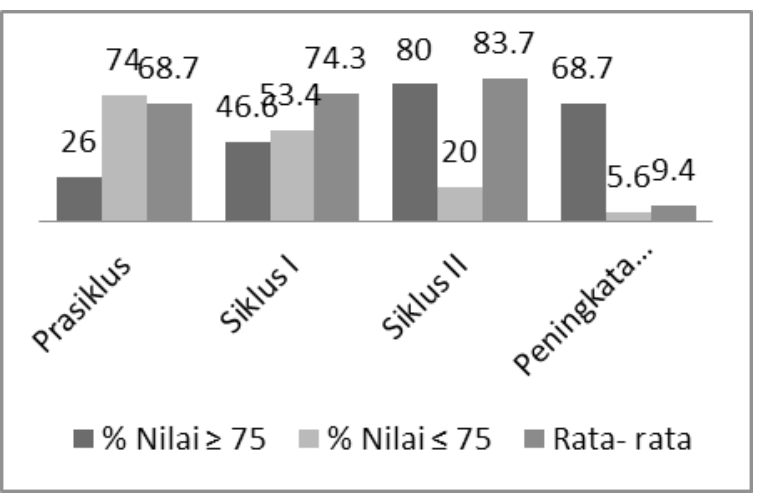

\section{Gambar 5 Peningkatan Ketuntasan Hasil Belajar Prasiklus (Siklus I dan Siklus II)}

Dari Gambar 5 tersebut dapat dijelaskan bahwa dari prasiklus rata-rata kelas $68.7 \%$ dengan siswa yang mendapat nilai $\geq 75$ sebanyak 8 siswa dan yang mendapat nilai $\leq 75$ sebanyak 22 siswa. Kemudian dilakukan siklus I dan di peroleh ratarata kelas $74.3 \%$ dengan siswa yang mendapat nilai $\geq 75$ sebanyak 14 siswa dan yang mendapat nilai 
$\leq 75$ sebanyak 16 siswa. Karena belum mencapai KKM mata pelajaran IPS maka dilakukan tindakan pada siklus berikutnya yaitu siklus II, diperoleh rata-rata kelas $83.7 \%$ dengan siswa yang mendapat nilai $\geq 75$ sebanyak 24 siswa dan yang mendapat nilai $\leq 75$ sebanyak 6 siswa. Dari hasil yang diperoleh pada siklus II maka tidak diperlukan siklus berikutnya. Adapun peningkatan ketuntasan hasil belajar siswa kelas 3 SDN Kranjingan 5 Jember mata pelajaran IPS materi jenis-jenis pekerjaan mulai dari tahap prasiklus, siklus I dan siklus II adalah dari nilai $68.7 \%$ menjadi 74.3 terjadi peningkatan sebesar $5.6 \%$ dan dari $74.3 \%$ menjadi $83.7 \%$ terjadi peningkatan sebesar $9.4 \%$.

\section{PEMBAHASAN}

Tujuan kegiatan belajar mengajar yang telah ditetapkan, dapat tercapai dengan lebih meningkatkan motivasi belajar siswa. Winkel menyatakan motivasi adalah semua yang berhubungan dengan timbul dan berkembangnya daya penggerak di dalam pribadi orang untuk melakukan aktivitas tertentu guna mencapai suatu tujuan (Zubaidah, 2001). Motivasi belajar merupakan suatu dorongan yang dimiliki oleh seseorang untuk meningkatkan dan mempertahankan kondisi belajarnya yang diwujudkan dalam aktivitas bersekolah. Kemampuan belajar dalam rangka memperoleh hasil belajar yang baik adalah sesuai dengan potensi dan kemampuan yang dimiliki. Jika seseorang mempunyai mempunyai motivasi besar, maka ia akan lebih giat untuk melakukan sesuatu tersebut dan demikian juga jika motivasinya rendah, maka untuk melakukan sesuatu juga rendah pula.

Motivasi belajar sangat penting bagi siswa. Pentingnya motivasi bagi siswa adalah menyadarkan kedudukan pada awal belajar, proses, dan akhir belajar, menginformasikan tentang kekuatan usaha belajar bila dibandingkan dengan temannya, mengarahkan kegiatan belajar, membesarkan semangat belajar, dan menyadarkan tentang adanya perjalanan belajar dan kemudian bekerja (Dimyati dan Mudjiono, 2006). Dalam hubungannya dengan kegiatan belajar mengajar, yang penting adalah bagaimana menciptakan kondisi atau suatu proses yang mengarahkan siswa melakukan aktivitas belajar. Memberikan motivasi kepada siswa berarti menggerakkan siswa untuk melakukan sesuatu atau ingin melakukan sesuatu kegiatan belajar sehingga akan menjadi kebiasaan dan kebutuhan untuk mencapai tujuan. Motivasi dalam kegiatan belajar mengajar merupakan keseluruhan daya penggerak di dalam diri siswa yang menimbulkan, menjamin kelangsungan, dan memberikan arah kegiatan belajar sehingga diharapkan tujuan belajar siswa akan tercapai (Sardiman, 2001). Motivasi belajar siswa merupakan dorongan yang membuat siswa semangat dalam belajar (Gunawan, 2007).

Hasil belajar merupakan capaian siswa dalam pembelajaran(Gunawan,2017). Hasilbelajaradalah tingkat pengetahuan yang dicapai peserta didik terhadap materi yang diterima ketika mengikuti dan mengerjakan tugas dan kegiatan pembelajaran (Ifa, 2013). Hasil belajar merupakan kemampuan yang diperoleh individu setelah proses belajar berlangsung, yang dapat memberikan perubahan tingkah laku baik pengetahuan, pemahaman, sikap dan keterampilan peserta didik sehingga menjadi lebih baik dari sebelumnya (Sjukur, 2012). Hasil belajar peserta didik berupa aspek kognitif, psikomotor, dan aspek afektif (Setiawan, 2008). Aspek kognitif meliputi penguasaan konsepkonsep dan prinsip-prinsip serta kinerja pemecahan masalah. Aspek psikomotor berupa keterampilan fisik dalam melakukan eksperimen (pengamatan). Sedangkan aspek afektif adalah sikap peserta didik terhadap pelajaran dan pembelajaran. Jika mengacu dari pendapat yang dikemukakan oleh para ahli, maka dapat disimpulkan bahwa hasil belajar adalah kemampuan yang dimiliki baik bersifat sikap (afektif), pengetahuan (kognitif), maupun keterampilan (psikomotorik) yang semuanya ini diperoleh melalui proses belajar mengajar.

Kemampuan cooperative learning dalam membangkitkan aktivitas sebagai indikator adanya minat belajar siswa selama mengikuti proses pembelajaran memang sangat dimungkinkan, karena pendekatan ini menekankan pada kerja sama antar siswa dalam kelompok kecil. Melalui proses kerja sama, gotong-royong, maka siswa dapat saling mengisi, bertukar pikiran sehingga semua siswa terlibat aktif. Oleh karena itu, pendekatan cooperatif learning dapat memberikan manfaat seperti dikemukakan oleh Pudjiastuti \& Dyah (2004), yaitu: (1) mendorong siswa belajar, bekerja dan bertanggung jawab dalam menyelesaikan 
tugas, baik tugas individual maupun tugas kelompok; (2) menumbuhkembangkan sikap dan perilaku demokratis, saling ketergantungan secara positif; dan (3) mendorong siswa yang pendiam (pasif) untuk ikut berperan aktif dalam proses pembelajaran.

Pembelajaran kooperatif memiliki ciri khusus yang harus diterapkan, meliputi: saling ketergantungan positif, tanggung jawab perseorangan, tatap muka, komunikasi antar anggota dan evaluasi proses kelompok (Lie, 2002). Salah satu model pembelajaran kooperatif adalah mencari pasangan (make a match) yaitu model pembelajaran yang penerapannya dengan menggunakan kartu bergambar sebagai media untuk memotivasi siswa sehingga mendapatkan hasil belajar yang lebih efektif dan efisien. Model make a match dapat meningkatkan ketrampilan siswa seperti menumbuhkan sikap saling menghormati, sikap kritis, sikap untuk selalu berprestasi, saling menghargai, dan sikap-sikap lain yang merupakan bagian dari tujuan pembelajaran IPS. Selain itu, Lie (2002) menyatakan salah satu keunggulan model ini adalah siswa mencari pasangan sambil belajar mengenai suatu konsep atau topik dalam suasana yang menyenangkan.

Pembelajaran model make a match dikemas dalam pembelajaran menggunakan kartu bergambar. Dengan adanya media ini, maka suasana pembelajaran akan menyenangkan dan dapat memotivasi siswa dalam belajar. Media berasal dari bahasa Latin medius yang berarti tengah, perantara atau pengantar pesan dari pengirim ke penerima pesan. Media dalam proses belajar mengajar cenderung diartikan sebagai alat-alat grafis, fotografis, atau elektronis untuk menangkap, memproses, dan menyusun kembali informasi visual atau verbal (Arsyad, 2009).

Penelitian yang dilakukan Winda (2010) menyatakan dalam pembelajaran kooperatif dapat membuat siswa bukan hanya belajar menerima apa yang diberikan oleh guru melainkan belajar dari siswa lainnya dan sekaligus mempunyai kesempatan untuk saling mengajar dengan siswa yang lain sehingga siswa nantinya akan lebih aktif baik dalam bertanya maupun mengemukakan pendapat. Dengan kondisi kelas yang demikian dapat menumbuhkan motivasi siswa dalam belajar, sehingga mempengaruhi hasil belajar yang akan dicapai olehnya.

Hasil penelitian Sispurwo (2011) menunjukkan bahwa model make a match dengan media kartu bergambar membuat siswa belajar dengan mengkonstruk pemahaman sendiri melalui interaksi sosial di dalam kelompok sehingga dapat meningkatkan motivasi dan hasil belajar siswa. Pandangan kontruktivistik adalah suatu filosofi yang mendasari belajar kooperatif, juga sebagai filsafat pengetahuan yang menekankan bahwa pengetahuan siswa adalah konstruksi dari siswa sendiri (Suparno, 1997). Sedangkan Keuchak (1998) menyatakan karakteristik pendekatan kontruktivis adalah siswa mengkonstruksi sendiri pemahamannya, dan belajar difasilitasi oleh interaksi sosial.

Pembelajaran kooperatif merupakan pembelajaran aktif yang menekankan aktivitas siswa bersama-sama secara berkelompok dan tidak individual, siswa secara berkelompok menemukan dan memecahkan masalah, pengambilan keputusan, berkomunikasi efektif dan bekerja sama (Hakim, 2008). Pendapat lain menyatakan pembelajaran kooperatif memberikan peluang kepada siswa yang berbeda latar belakang dan kondisi untuk bekerja saling bergantung satu sama lain atas tugastugas bersama dan melalui penggunaan struktur penghargaan kooperatif, belajar untuk menghargai satu sama lain (Trianto, 2007).

\section{SIMPULAN DAN SARAN}

\section{Simpulan}

Simpulan penelitian ini adalah penerapan pembelajaran model make a match dapat meningkatkan hasil belajar IPS materi jenisjenis pekerjaan. Model ini menekankan adanya pembelajaran mengenai konsep dengan cara mencari pasangan melalui media kartu bergambar. Aktivitas pada model make a match memotivasi siswa kelas III pada saat pembelajaran sangat positif. Berdasarkan hasil pengamatan observer dan hasil wawancara, menunjukkan bahwa keseluruhan pembelajaran materi jenis-jenis pekerjaan pada kategori baik. Hasil wawancara menunjukkan bahwa siswa menyukai belajar IPS pada materi jenis-jenis pekerjaan dengan model make a match . 
Hasil belajar yang diperoleh siswa mengalami peningkatan, mulai dari prasiklus, Siklus I, dan Siklus II. Siswa termotivasi selama proses pembelajaran dengan model make a match dengan bantuan kartu bergambar, siswa lebih memahami contoh dari materi jenis-jenis pekerjaan. Selain itu, ketika siswa mencari pasangan mereka dituntut untuk sportif dan tidak membeda-bedakan suku maupun bahasa.

\section{Saran}

Saran yang dapat diberikan bagi guru adalah sebaiknya menjadikan pembelajaran model make a match sebagai suatu pembelajaran alternatif yang layak dipertimbangkan dalam pembelajaran materi jenis-jenis pekerjaan. Guru hendaknya memberikan kesempatan dan motivasi yang maksimal kepada siswa untuk aktif mengemukakan pendapat dan mengajukan pertanyaan dalam pembelajaran model make a match agar siswa tidak merasa bosan dan tetap berkonsentrasi penuh pada pembelajaran. Guru hendaknya memberikan perhatian yang lebih besar kepada siswa yang berkemampuan rendah dengan cara melakukan pendekatan untuk mengurangi ketertinggalan tersebut dari teman yang berkemampuan sedang dan tinggi dalam mempelajari materi. Perlu menyiapkan rencana pembelajaran dengan baik agar penerapan pembelajaran model make a match berjalan dengan baik dan memahami setiap rangkaian tahap pembelajaran yang dilakukan. Guru sebaiknya mengajak siswa agar selalu interaktif dalam bertanya-jawab tentang materi yang disampaikan dengan menunjuk nama maupun memberi kebebasan kepada seluruh siswa sehingga dapat menarik perhatian seluruh siswa.

\section{DAFTAR RUJUKAN}

Arends, R. I. 2004. Learning to Teach. Sixth Edition. New York: McGraw-Hill Companies.

Arsyad, A. 2009. Media Pembelajaran. Jakarta: PT Grafindo Persada.

Dimyati, \& Mudjiono. 2006. Belajar dan Pembelajaran. Jakarta: Rineka Cipta.

Gunawan, I. 2007. Hubungan Keterlibatan Guru dalam Musyawarah Guru Mata Pelajaran dan Kemampuan Mengelola Kelas dengan Motivasi Belajar Siswa di SMA Negerise-Kota
Malang. Skripsi tidak diterbitkan. Malang: Fakultas Ilmu Pendidikan Universitas Negeri Malang.

Gunawan, I. 2017. Penerapan Manajemen Pembelajaran Berbasis Lesson Study dan Dampaknya terhadap Keaktifan Mahasiswa dalam Perkuliahan. Jurnal Pendidikan dan Pembelajaran, 24(1), 126-138.

Hakim, L. 2008. Perencanaan Pembelajaran. Bandung: CV Wacana Prima.

Ifa, M. 2013. Penerapan Model Pembelajaran Kooperatif Tipe Jigsaw untuk Meningkatkan Hasil Belajar Siswa Kelas X SMK Negeri 3 Boyolangu pada Standar Kompetensi Menerapkan Keselamatan dan Kesehatan Kerja (K3). Jurnal Pendidikan Teknik Elektro, 2(2): 715-722.

Keuchak. 1998. Learning and Teaching (Reseach Bassed Method). Needham Height: Allyn and Bacon a Viacom Company.

Lie, A. 2002. Cooperatif Learning. Mempraktikkan Cooperative Learning di Ruang-Ruang Kelas. Jakarta: PT Gramedia.

Pudjiastuti \& Dyah, S. 2004. Metode Pembelajaran. Malang: Universitas Negeri Malang.

Sanjaya, W. 2009. Kurikulum dan Pembelajaran: Teori dan Praktik Pengembangan Kurikulum Tingkat Satuan Pendidikan (KTSP). Jakarta: Kencana.

Sardiman. 2001. Interaksi dan Motivasi Belajar Mengajar. Jakarta: Raja Grafindo Persada.

Setiawan. 2005. Interaksi dan Motivasi Belajar Mengajar. Jakarta: PT Raja Grafindo Persada.

Setiawan, I. G. A. N. 2008. Penerapan Pengajaran Kontekstual Berbasis Masalah untuk Meningkatkan Hasil Belajar Biologi Siswa Kelas X-2 SMA Laboratorium Singaraja. Jurnal Penelitian dan Pengembangan Pendidikan, 2(1),42-59.

Sispurwo, J. 2011. Peningkatan Hasil Belajar dan Motivasi Siswa Kelas 3 pada Pelajaran IPA melalui Model Make a Match Dipadu TPS (Think-Pair-share) SD Negeri Ardirejo Kepanjen. Tesis. Bandung: PPS UPI.

Sjukur, S. B. 2012. Pengaruh Blended Learning terhadap Motivasi Belajar dan Hasil Belajar Siswa Tingkat SMK. Jurnal Pendidikan Vokasi, 2(3): 368-378. 
Slavin, R. E. 2006. Educational Psychology: Theory and Practice. Boston: Pearson Education, Inc.

Slavin, R. E. 2008. Educational Psychology. Massachusetts: Allyn \& Bacon.

Suparno, P. 1997. Filsafat Konstruktivis dalam Pendidikan, (cetakan kelima). Yogyakarta: Penerbit Kanisius.

Susilo, H., Chotimah, H., \& Sari, Y. D. 2008. Penelitian Tindakan Kelas Sebagai Sarana Pengembangan Keprofesionalan Guru dan Calon Guru. Malang: Bayumedia Publishing. Trianto. 2007. Model-Model Pembelajaran Inovatif Berorientasi Konstruktivistik. Jakarta: Prestasi Pustaka.
Winda, A. 2010. Penerapan Pembelajaran Kooperatif Model Make a Match untuk Meningkatkan Hasil Belajar dan Motivasi Siswa pada Pelajaran Bahasa Indonesia Siswa Kelas 4 SD Negeri Rungkut 01 Surabaya. Tesis. Surabaya: PPS UNESA.

Winkel, W. S. 1996. Psikologi Pengajaran. Jakarta: Gramedia Widiasarana Indonesia.

Wiraatmadja, R. 2007. Metode Penelitian Tindakan Kelas. Bandung: PT Remaja Rosda Karya.

Zubaidah, S. 2001. Efektifitas Pengelolaan Kelas dan Hubungannya dengan Motivasi Belajar Siswa SMU Negeri Se-Kota Malang. Skripsi tidak diterbitkan. Malang: Fakultas Ilmu Pendidikan Universitas Negeri Malang. 